\title{
4 \\ Negotiating the boundaries of nursing practice
}

Captain Johnson, the dental officer, a quiet man, spoke next. 'Treat for shock. Pick out any loose teeth and bits of bone then put a stitch through the tongue and tie it to a button on his jacket before you send him down the line on a stretcher'. His audience winced. Civvy nursing was never like this. These notes were probably intended for medical officers originally but they startled us into thinking objectively about the kind of nursing we might expect on active service. ${ }^{1}$

This quotation comes from Brenda McBryde's published memoir written nearly 50 years after the end of the Second World War. It is therefore prone both to relating the dramatic interventions required to engage a readership, and the nostalgia invoked by nurses when they considered their wartime lives. Nevertheless, it demonstrates the new surgical work that nurses expected to encounter as part of their overseas duties. Student nurses who trained between 1939 and 1945 cared for civilians injured by enemy bombing campaigns and combatants evacuated back to Britain from war zones. Thus, even before overseas posting, many nursing sisters had some experience of the horror of wounds caused by industrial weaponry. However, as suggested in the quotation above, the exigencies of active service, including the often limited access to medical officers, demanded innovative and rapid nursing responses to the life-threatening injuries of an increasingly technological war. ${ }^{2}$

Using surgical nursing in war as a 'case study' for developments in nursing practices and professional autonomy, the chapter examines the changes to the domain of their work by nursing sisters on active service overseas. The first section explores extensions to the nursing role, most particularly in the care of wounds and burns. Both of 
these areas of practice were part of the inventory of traditional nursing work, but the pressures of war demanded that all nurses should become adept at dealing with ever more complex treatments. Crucially for nursing sisters on active service, they were increasingly in charge of treatment regimes without medical supervision. The second section explores the expansion of nursing duties, those that had hitherto been the domain of medicine. These roles included the commencement and management of blood transfusions, surgical work and anaesthesia. The chapter's third section considers 'new work', the most critical of which was the administration and use of penicillin, although it is acknowledged that the utility of this drug went far beyond the treatment of surgical patients. This 'miracle drug' was one of the most important clinical developments for both medicine and nursing. Furthermore, because neither profession had previous experience with it, they needed to learn together, creating new lines of inter-professional relationships.

During the Second World War it was expected that women would become active citizens to help the war effort, but within the accepted gender constructions of femininity, ${ }^{3}$ that is, maintaining a supportive and domestic sphere. ${ }^{4}$ However, the importance of developing more collaborative working relationships between doctors and nurses was appreciated from the early months of the war, when the War Office ordered that RAMC medical officers and QAs attend gas courses together. ${ }^{5}$ The placing of nurses and doctors in the same classroom as equals, even though it was not for clinical lectures, reveals the contradictory attitudes to men and women's participation in war. The male authorities both wanted and did not want there to be equal gender relations. Female nurses may have been very much the subordinate gender and profession in civilian hospitals, but the proximity of living and working quarters in a war zone made the continuation of the hierarchy difficult. Learning non-clinical skills together could facilitate the team-work that would be needed to recover men for battle. For nurses as members of the military posted overseas, edicts about femininity were increasingly difficult to follow, and untenable in the face of the proliferation of complex injuries and the new technologies developed to treat them. ${ }^{6}$ As doctors on active service overseas established more collaborative relationships with nursing sisters outside the hospital wards and witnessed their work and apparent 
capabilities within those wards, they learnt to trust nurses to take on more complex work with less supervision and direction.

\section{Shifting work and gender boundaries}

As nurses extended and expanded their work beyond the 'normal' remit of nursing practice, ${ }^{7}$ the gender and professional boundaries between medicine and nursing blurred. On active service overseas nurses increasingly 'stood in' for their medical colleagues as the exigencies of war demanded. One sister, part of the BEF evacuating Marseilles in June 1940, wrote that the colonel of her unit asked her about the medical fitness or otherwise of the patients: 'He said he could not find the M.O. to ask him. I gave my opinion.' ${ }^{8}$ Sister Mary Morris's diary states that she and her colleagues, 'examined each man, carefully, referring any urgent cases to Col. Cordwell'. ${ }^{9}$ Others prescribed and administered pain relief without a medical officer. ${ }^{10}$ Sister Betty Parkin recalled passing a naso-gastric tube for a doctor when he was unable to do so. ${ }^{11}$ Sister Angela Bolton maintained that 'The medical officers and sisters worked much more as a team than they did in hospitals back home. The unquestioning reverent obedience to doctors that had been instilled into us when we had been training had changed to an easy comradeship that made life pleasanter and more productive of ideas for the patients' welfare. ${ }^{12}$ Others wrote of 'rank [being] barely recognised'13 and doctors helping the nurses on the ward as they created order out of the chaos of convoys. ${ }^{14}$ Yet nursing sisters did not experience this new confidence without some hostility; not all relations in the field were harmonious. Sister Helen Luker experienced difficulties with the medical staff on the HMS Dorsetshire, both clinically and professionally. On 7 November 1940 she complains that 'Col Ward demands tea at $4.30 \mathrm{pm}$ to my intense annoyance'. ${ }^{15}$ Then, on 20 December 1940 she wrote:

\footnotetext{
We are just cleaning up after the transfusion when Pte Hughes, a gunshot wound of arm in plaster [sic] has a secondary haemorrhage. I have great difficulty in calling Capt. Robertson and when he comes he's not very helpful. We give packets of morphine and pray hard. I go to Capt. R twice more, but he doesn't think fit to get up \& help us, so I do what I think is best. But Garland + I are simply shaking with anxiety + there are lots of other ill patients as well. ${ }^{16}$
} 
Parkin's irritation was reserved for a medical officer who would not even let the nurses organise the diets, something she felt was entirely the province of nurses and not doctors. ${ }^{17}$ Hutchinson wrote of a particular doctor, who having ordered a nursing sister to give a drug intramuscularly that should have been administered intravenously (IV) let the sister take the blame for the blunder. When this medical officer then asked Hutchinson to give the drug IV, she refused, stating, 'No, I do not have to. I am a Registered Nurse, and if I do not consider I am qualified to give a drug intravenously, I am entitled to refuse. I hereby refuse. ${ }^{18}$ Sister Joan Nicolson recalled the debacle following her refusal to work with a doctor who, she felt, had been overly harsh to a very young soldier who had deserted: 'And so of course I was in grave trouble because it was considered insubordination and his rank was major and I was only a lieutenant.' She was hauled in front of the colonel commanding her unit and informed him that 'I believed we should be sanctuary for people brought in'. ${ }^{19}$ Although clearly guilty of insubordination, she was not disciplined. More importantly, both her behaviour and that of Hutchinson demonstrate a strength of will and professional confidence despite official medical superiority.

During the First World War men did not always appreciate being ordered by women, especially if those orders involved painful and arduous treatment regimes. ${ }^{20}$ Despite the 20-year gap, many men had not altered their attitudes significantly. ${ }^{21}$ Nurses were not necessarily allowed to enjoy professional autonomy in the same way that men did. Just as the Army needed to rely on the self-control of soldiers in far-flung war zones where the lines of authority were fewer, ${ }^{22}$ so nurses were enabled to be more autonomous in these theatres of war, but this autonomy was contingent on geography and the levels of medical officer cover. ${ }^{23}$ The closer to home and civilisation, the fewer the opportunities for new ways of practice, something that would have a lasting effect in the aftermath of war. Despite these impediments to the new working practices of nursing sisters, they managed to develop their role in new and professionally legitimating ways.

The adoption of 'medical' tasks by nurses was not new and there had always been a body of nurses who had little use for the constraints of professional boundaries. ${ }^{24}$ Where they saw a problem, they dealt with it. ${ }^{25}$ As medical technologies became commonplace - such as the thermometer in the early twentieth century, the sphygmomanometer 


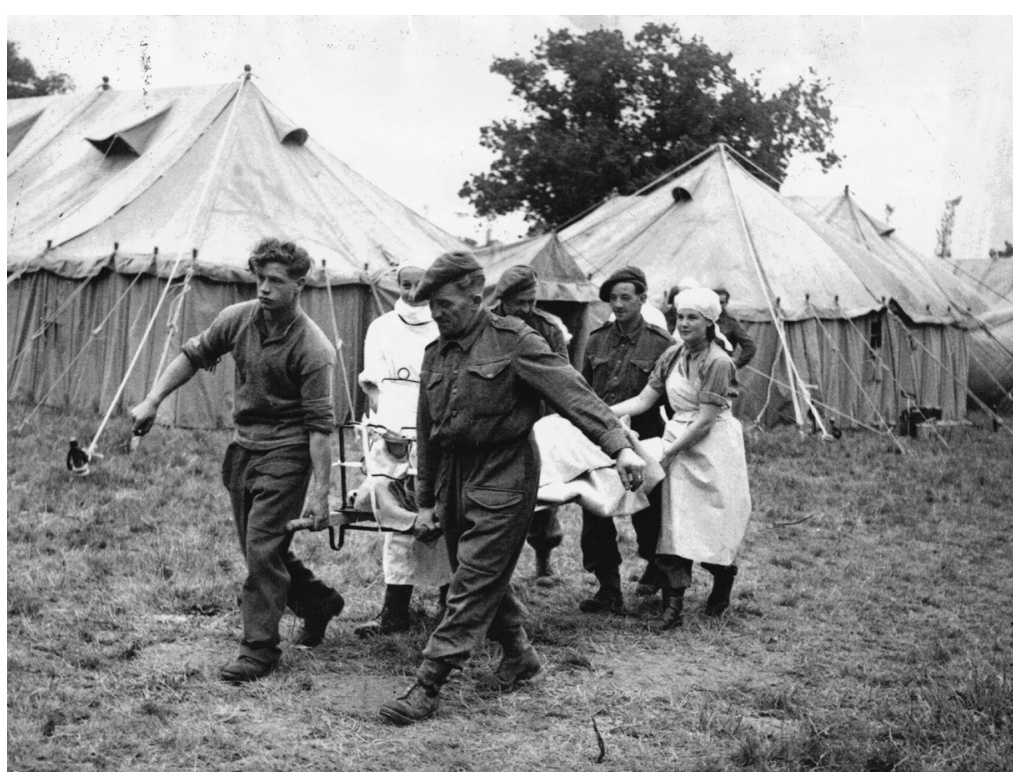

8 Italy. Sisters and RAMC orderlies carrying out a patient. This image reveals the collegiality between different members of the medical team.

Such relationships were essential for successful patient care in active service conditions.

(the instrument used for taking blood pressures) and the monitoring of intravenous infusions in the inter-war period - doctors were pleased to hand over this now mundane work. ${ }^{26}$ However, on active service overseas nurses were required not only to take over technologies from their medical colleagues ${ }^{27}$ but also to develop skills with new technologies alongside doctors, thus shifting the balance from learning 'from' the medical profession to learning 'with' medical colleagues.

\section{Extending nursing work}

\section{Wound care}

The exigencies of war had a profound effect not only on those nurses who were posted overseas but also those nurses and probationers who were required to care for combatants on British soil after ill 
and injured soldiers were evacuated back to 'Blighty'. ${ }^{28}$ Traditional hospital 'dressing rounds', as they were called, followed an ordered formula, with little room for individual decision making. In a hospital system where student nurses performed the majority of nursing work, such formulaic practice made perfect sense. Nurses needed to be able to care for patients with 'unconscious competence', in order to prevent accidental harm. ${ }^{29}$ There were aspects of the dressinground ritual that included some level of decision making, such as not beginning dressings until after the dust had settled following the daily cleaning regime. Changeable criteria that required skills in negotiating indeterminacy, ${ }^{30}$ such as beginning with the cleanest wounds and leaving the most dirty or infected wounds till the end, thereby altering the organisation of the round, were not necessarily part of the process. ${ }^{31}$ The onslaught of injured men from battle denied the hospital-ward dressing round its ritual. Nurses needed to develop more reactive nursing skills rapidly. Morris's experiences as a student following the evacuation of soldiers from Dunkirk were to provide excellent training for her overseas postings:

As I entered the Casualty department, I was astounded to see so many wet, dirty and injured people there. Some were soldiers (I guessed they must be Dunkirk survivors), others were civilians ... they were all laid out on stretchers on the floor, and most of our surgeons and physicians were there, assisted by several senior Sisters and Staff Nurses. I was given the job of removing dirty wet clothing, so that they could be examined by the doctors. Several men had their skin flayed by oil burns, a very painful condition, others were injured by bomb splinters, and some injured by machine gun fire from the air as they came across the Channel. ${ }^{32}$

Sister Penny Salter's recollections of the arrival of convoys from Dunkirk, when she was a student, invoke the same level of suffering. Like Morris, the work caring for the survivors would prepare her partly for the challenges that she would face when posted overseas:

At 2.30 am we ran across the grounds and down the long cold and dreary corridors of Park Prewett Hospital meeting on the way the male orderlies, strangers to us, of whom we learned at a later date were volunteer pacifists who had been up all night helping with the evacuation of the hospital ... on that May morning in 1940, the ambulances began to arrive, carrying the maimed, the lame and the blind. Many were on stretchers, others limping along supported by weary comrades clinging to them. 
Everything here was well organized, the teamwork between doctors and nursing staff was outstanding, not a moment was lost in dealing with the terrible injuries we had to face: foul, putrid festering wounds that stank to high heaven, sustained by men of remarkable courage.

Our first task was to get them bathed and cleaned up before putting them to bed in to cool crisp sheets, but this was not easy as their feet was [sic] the problem. Their feet were in such a terrible state that even after soaking we had to cut their boots off.

The stench of dried blood and gangrenous flesh was nauseating. I remember so well asking an orderly to stay with one of my patients for a short while as, so like many of my colleagues I went outside and was violently sick ... the stench remained in my nostrils for days. ${ }^{33}$

These experiences as students may have prepared them for the smell and decay of war injuries, but the challenges of work on overseas postings stretched the Army nurses' expertise 'to capacity'. ${ }^{34} \mathrm{On}$ active service the limited access to medical staff, the severity of the injuries that required dressings, the sheer numbers of combatants arriving needing nursing care, the complexities of the wounds and the prolonged period between the wound being sustained and the access to a qualified nurse conspired to create the 'perfect storm' of work. ${ }^{35}$ In a 1940 publication designed to prepare the nurse for war service, the work of the surgical nurse is described as, 'a strange experience ... at the beginning they will often be shocked by the physical enormities that are inevitable in war as it is waged to-day'. ${ }^{36}$

Many of the complex wounds that nurses were required to dress on active service overseas would have been seen to by medical staff, or at least under supervision of a doctor in civilian practice. Bruce Dick, a consulting thoracic surgeon, wrote that war nurses would need 'resourcefulness in certain emergencies' that perhaps had hitherto not been necessary. ${ }^{37}$ In his letter to The Lancet, John Elam maintained that nurses and other first-aid workers should all be trained in gas and air analgesia 'for the dressing of war wounds'. ${ }^{38}$ Morris was clearly proud of the 'resourcefulness' of their surgical team in Normandy: 'Another new M.O. arrived here today. He is very pleasant but rather astonished by our unconventional methods of surgery and post operative [sic] nursing. We have all learned a great deal here, mainly by trial and error. Necessity has created a great deal of inventiveness. 39 
In the wars of the twentieth century, hospitals could provide valuable respite for battle-exhausted soldiers, but the injuries sustained also created the need to perform what could seem like barbaric surgical interventions. ${ }^{40}$ Nursing sisters knew that it was their 'meticulous care in regard to asepsis at all times, in spite of hectic rushes [which] may mean the difference of a man keeping or losing a limb'. ${ }^{41}$ However, sometimes men arrived having had the amputation in the field, using brutal methods developed to prevent gangrene. In June1940, the Nursing Times informed its readers that in order to prevent gangrene spreading through the stump flap following amputation, 'a new and drastic form of amputation - known as a guillotine amputation - was introduced'. ${ }^{42}$ In the desert war from late 1941, nurses were witnessing and writing about the damage that this method caused. One TANS sister wrote to Dame Katharine Jones expressing her distress over the 'Many limbs [that] had to be reamputated as the first operation had been performed up in the front line C.C.S. by Greek M.O.s. The limb had been cut off, arteries tied and a dressing applied leaving a great raw wound that could never heal. It was very difficult to make the patients understand why they must have a second operation. ${ }^{2} 3$ It is unlikely that even as Matron-inChief, Jones was able to affect the decision to stop using the guillotine method, but, critically, nurses were gaining in confidence to question surgical practice. Furthermore, they needed to use all their skills to support their soldier-patients for future surgery.

The extension of nurses' work with war injuries thus gave rise to new demands for psychological care. It was of vital importance for nurses 'to gain the patient's confidence and co-operation' in order to provide life-saving and -affirming treatments. ${ }^{44}$ Morris wrote in her diary of her concern for one lieutenant who had sustained an abdominal wound during the fighting at Arnhem in the autumn of 1944: 'Brian will be alright physically once the wound has healed but I think it will be a long time before he gets over the shock of Arnhem. Connie tells me that he has to be constantly sedated at night to stop him screaming in terror. He is only twenty-two years old. ${ }^{45}$ Sister Catherine Hutchinson's greatest sympathies lay with her patients who had colostomies. Medical authorities knew that in order for abdominal injuries to have any hope of healing, immediate surgery was needed, but this led to men being operated upon and then 
having days before any further treatment. ${ }^{46}$ Many of Hutchinson's patients had sustained gunshot wounds to the abdomen and then had travelled by train through Italy to Naples before being admitted to her ward on HMS Empire Clyde:

During these days - for days it was - rather than hours - some of them had not had their dressings (they had not got to the stage of bags yet) properly changed - just more padding added as the bandages became stained with faecal fluid. They bulged horrifically as if bearing a pillow over their abdomen. If the ship was in the Naples harbour they came direct to us exhausted, apprehensive and stinking ... I took note of such patients, knowing that I would have to struggle to undo the work of neglect ... When all the dressings were off, a sorry state was revealed. Because most of them were recent casualties, the outpourings were mostly fluid or semi solid; the acidity in the fluid had excoriated the skin around the opening in a wide area, leaving most of the abdomen red and sore, with broken skin around the actual opening. ${ }^{47}$

Hutchinson's acknowledgement of the scale of her responsibility for the wounded men is tempered by her understandable dismay at their surgery and the realisation that she will need to do more than just care for the men's physical needs. Evidence of sporadic and occasionally successful performance of colostomies can be found from the eighteenth century. According to Dorothy Doughty, in one of the only historical essays on stoma surgery, by the twentieth century colostomies had become a realistic treatment option, although the products to support colostomy care were still in their infancy. ${ }^{48}$ The horror of the colostomy was not lost on the nurses or medical staff. The narrative of the disgust that a stoma creates in people was exemplified in the 1956 propaganda film The Feminine Touch. ${ }^{49}$ In the film, designed to improve recruitment and retention in the postwar nursing profession, ${ }^{50}$ the character of the matron uses the tragedy of the colostomy to dispel any question as to the vital importance of the nurse's work in psychological as well as physical rehabilitation of the patient with a stoma. It is the nurse, the matron argues, and her response to the stoma that makes the difference to whether the patient can also accept the surgery. Even though Hutchinson maintained that she never had more than two colostomy patients at once, ${ }^{51}$ the stench from dressings that had not been changed since the original operation in the claustrophobic atmosphere of a hospital ship would 
have increased the revulsion for all concerned. As the nursing sister in charge of the ward, Hutchinson's commitment to extending her nursing skills was paramount to recovering the men.

The new technologies of the Second World War created advanced weaponry that could maim and harm with extensive and devastating consequences. The medical services were challenged to respond rapidly and with the requisite skills to save life. Some of the worst examples of these assaults on the human body involved burning. Many nursing sisters had some experience of caring for burns and some had received special post-registration training. Brenda McBryde attended the burns course at Bangor that had been instituted in the wake of the terrible injuries that had been sustained by airmen in 1940 during the Battle of Britain. ${ }^{52}$ Not all of the nursing sisters were so fortunate to receive specialist training prior to their overseas posting. All were shocked at the havoc that burns wreaked on their victims, whether from aircraft that went up in flames, burning oil as ships sank or being trapped in tanks. ${ }^{53}$ The developments in burns treatments meant that nurses were confronted with new and constantly evolving therapeutic regimes to salvage their soldier-patients.

\section{Burns}

E.C. Davidson 'revolutionised' burns treatment in 1925 when he introduced tannic acid. By the beginning of the Second World War the use of tannic acid for burns had been standardised and it was believed that their treatment therefore would cause 'little difficulty'. ${ }^{54}$ In July 1940, in an article examining the treatment of incendiary bomb burns, the advice from Dr R.G. Henderson was that tannic acid of a strength varying from 5 per cent to 20 per cent should be either sprayed or dabbed with gauze onto the burn. If this was then followed by an application of 10 per cent silver nitrate solution, a protective crust would be formed. ${ }^{55}$ By November of that year the Nursing Mirror was alerting its readers to the cessation of using tannic acid routinely for burns. ${ }^{56}$ Nurses were alerted to the dangers of tannic acid in the treatment of third degree burns and those on the hands and face, because of the extensive scarring and contractions that it could cause. ${ }^{57}$ Most nursing staff would not necessarily have been aware of the research into the treatment of burns with tannic acid, 
but, even as a junior probationer, Morris would bear witness to the damage that it created when used on the hands and face:

Private Brian M. is one of the most severely burned. He is about eighteen years old - my age. His face and hands have been sprayed with tannic acid, which has set into a hard black cement. His arms are propped up in front of him on a pillow, the fingers extended like claws and his naked body hangs loosely on straps just clear of the bed..$^{58}$

Yet as nurses observed the catastrophe of burns, they were not always passive onlookers. Because all the methods of treating burns were dependent upon the nursing care, ${ }^{59}$ their observations would enable them to support developments in burns care as the war continued. One anonymous sister in the Middle East noted that 'dyes, e.g. Triple dye treatment of burns was not a success in the topics' ${ }^{60}$ Another nursing sister was posted to Gibraltar between 1940 and 1942: 'I had ample opportunity of [sic] observing and comparing the merits of modern treatment for burns: tannic acid, triple dye, Vaseline and sulphonamide powder, saline baths and dressings, and I was much impressed by the excellent results obtained by enclosing limbs for several weeks in Plaster of Paris. ${ }^{31}$ Sister V. Shennan's extensive notes sent to Dame Katharine Jones in 1943 from the Middle East on the care of the burns patient and the complex arrangements for treatment regimens suggest the close involvement of nurses in decisions regarding the needs of the patient. For example, she identified the actions to be taken in the case of a reaction to blood transfusions, the protocols for dressings and contra-indications to sulphonamide 'emulsions'. ${ }^{62}$

By 1941 the treatment for burns had developed significantly, following knowledge gained in the first two years of the war. Wing Commander Stanford Cade of the RAF acknowledged the worth of tannic acid and its life-saving value in civilian life, but argued that the nature of 'Airman's burns' was such that its benefits were reduced. ${ }^{63}$ Tulle gras dusted with sulphanilamide and kept moist with saline drips was now the treatment of choice for many burns. Where the burns affected limbs, jaconet or silk bags were recommended to retain the moisture and promote healing. ${ }^{64}$ These new treatments were also less painful than tannic acid. ${ }^{65}$ The alternative was the envelope or Bunyan method, named after John Bunyan, the surgeon who 
invented it. In 1942, Archibald McIndoe was advocating tannic acid and silver nitrate for non-functioning parts of the body, such as the back or abdomen. ${ }^{66}$ However, for burns to the hands and face or in the case of third degree burns he argued for the use of sulphanilamide tulle gras moistened with saline, if possible in conjunction with saline baths. ${ }^{67}$ Despite these new treatment options, the debates as to the relative harms and benefits of tannic acid and other regimens continued throughout the war. In her diary entry for 9 November 1944, Bolton wrote of a patient who was 'the worst case of burns I have seen out here, three-quarters of the skin surface being involved ... we badly need a breakthrough for burns' ${ }^{68}$ Despite the developments in burns care, even in the latter months of the war, the choices were limited and success rates not certain.

Like Morris and Salter, Sister Ann Radloff gained useful experience in caring for injured soldiers as a student nurse in Britain, including those who had been burnt. In her memoir, she recalled the archaic nature of tannic acid and other topical treatments and demonstrated a prescient understanding of the regimes for shock:

The troopship Lancastria was bombed and sunk off Cherbourg. Very few of the survivors could walk - how can you when you have been covered in flaming oil? Those were the days of Tannic Acid (sometimes even cold tea leaves were used) for treatment of burns. And the Bunyan bag was an enormous cellophane container filled with saline into which charred limbs were inserted to be entirely surrounded by fluid. Corporal C. - 'Jock' - was an unrecognizable human hulk with a human soul. He had been enveloped in burning oil and as a living torch had jumped into the sea. Perhaps the salt water saved him but the oil was thick and cohesive and had burnt right through to the tissues. Jock had to be moved and turned - worst of all he sometimes had to be lifted onto a bedpan. The skin contracted and Jock was never free from pain unless mercifully drugged with morphine ... All severe burns cases suffered from dehydration which can be remedied by a saline drip, if, as in Jock's case the lips are too corroded and swollen and the tongue too painful for fluid to be given by mouth. But they could not find a vein in Jock's charred body. So Corporal C. died ...69

Others were luckier and the sea did in fact save them. Betty Evans, working as a student nurse in London during the Dunkirk evacuation, noted 'a terrific number of pilots baling with dreadful burns, baling out into the sea ... but the pilots were baling out into the flames and so had dreadful burns, but the ones who were in the water, because 
of the saline, their skin grafts did better. ${ }^{70}$ Sisters Geraldine Edge and Mary Johnstone were posted to the Hospital Carrier Leinster, from where they evacuated patients between Naples and Anzio. On one such trip they embarked 30 American sailors, all of whom had been burnt when their ship was torpedoed: 'hours of immersion in cold water seems a harsh method of dealing with such cases, but the effect of salt water on burns is found to be extraordinarily good and strangely enough the ensuing shock is less'. Although at least one did die, many survived. ${ }^{71}$

Too often, as Lt-Colonel Norman Logie (RAMC) wrote in The Lancet of his experience in caring for burns victims in the desert, there were no nurses. Although, as he maintained, the orderlies did what they could to support the healing of burns patients, 'they were not nurses and they were few in number'. They needed simple regimes that were not affected by the frequent dust storms and the need for lengthy evacuation journeys. He therefore recommended tannic acid and silver nitrate for burns, but not of the hands and face, which should be treated with tulle gras soaked in sulphanilamide. ${ }^{72}$ However, he cautioned over the possible toxicity from contact of sulphanilamide with raw areas that could raise the blood concentration to a 'dangerous level'. ${ }^{73}$ By 1944 penicillin was available for burns, thus theoretically rendering such concerns obsolete. Evans, who landed with the Second Front into France in 1944, recalled using penicillin in conjunction with tulle gras on the burns of men who had been trapped in tanks, but there were fears that penicillin would not be beneficial in all burns cases. ${ }^{74}$

Although tannic acid in conjunction with silver nitrate was an uncertain cure, according to Brigadier Philip Mitchiner, honorary surgeon to the king, it was useful as a first-aid measure in many burns, except those on the face and hands, and was particularly useful in preventing shock. ${ }^{75}$ McIndoe wrote in the Nursing Mirror that 'the first and most important thing is the control of shock. This takes precedence over any form of local treatment, apart from the protection of the burn and the dusting on of sulphanilamide powder.' PMRAFNS Sister H.B. Woods also claimed precedence for the treatment of shock as the primary concern, followed by the prevention of infection. ${ }^{76}$ Woods' dictum that these were the primary responsibilities for nurses in burns cases is critical, given their position in the 
overseas military medical service. She recommended the treatment of shock by warming the patient with electric blankets and hot-water bottles and then the administration of warm fluids orally, per rectum or intravenously ${ }^{77}$ - work which would have been understood as nursing. Evans maintained that even in the summer of 1944 they had the 'medical staff putting up the drips', ${ }^{78}$ yet many nurses had taken on IV therapy as part of their nursing role. The administration of IV plasma had become a nursing duty before the war, but the frequency of infusions and the lack of medical staff to monitor them on active service overseas meant that its place in the lexicon of nursing work increased. As the war raged around the nurses at the Anzio beachhead, one nurse wrote that: 'In the Post-Operative Ward it was unusual to find a patient who was not having either blood or plasma, and the care of the "drips" was one person's constant work. ${ }^{79}$ In an article to the Nursing Mirror on 2 September 1939, the day before war was declared, nurses were informed that their duty was: 'The care of the recipient, which will include the preparation of the site to be used ... sterilising and the preparation of the necessary apparatus ... the doctor ... controls the flow when the apparatus cannot be adjusted and safely left without attendance. ${ }^{30}$ As the long years of the war progressed and realisation grew of the changing requirements that were being placed on the medical services, the roles of the nursing staff needed to expand to this challenge.

\section{Expanded nursing work}

\section{Transforming transfusions}

Our Medical Office [sic] being so busy receiving patients could not always be present at admissions. This was to our advantage as we became well acquainted with the stethoscope and commenced to do our own investigations for diagnosis, to be checked later by the Medical Officer. Besides becoming quite adept at diagnosing we learned to do many treatments which we would not be allowed to do at home. What a great thrill I had at setting up my first blood transfusion. ${ }^{81}$

Whether in Britain or on active service overseas, when medical officers could not be spared to monitor blood transfusions, such work was passed to the nursing staff. Thus, by 1943, June Hamilton stated, even student nurses in Britain were monitoring the blood flow of a 
transfusion and it was accepted that the staff nurse would take action if the flow stopped. Only if the staff nurse could not start the flow again would the registrar be informed. ${ }^{82}$ According to Margarete Sandelowski, the delegation of work because of the inconvenience of mundane activities to the medical profession maintained a strict hierarchy between professions and, by implication. gender. ${ }^{83}$ Nurses' duties expanded into key positions in the resuscitation wards on active service overseas, work that was critical in restoring men with shock before surgery. The right of the medical staff to dictate that work had not altered. McBryde recalled the order: 'Quarter of morphia, Sister. Straight away. Two pints of blood, one of plasma. ${ }^{\text {'4 }}$ At times, nurses were simply unable to find a medical officer when the convoys arrived, and their willingness to start transfusions without medical supervision was paramount if men were to survive. ${ }^{85}$ As Sister P.M. Dyer's quote above demonstrates, British nurses were excited rather than alarmed when war brought with it a range of new tasks, and did not necessarily view the delegation of the work as a sign of their subservience.

The limited access that British women had to the medical profession in the early years of the twentieth century meant that few considered it as a real option. This left nursing as the natural choice for those who wished to care for the sick and support the health of the community. ${ }^{86}$ At least two of the nurses' testimonies used in this book identify that they had brothers who were either doctors or officers in the war, suggesting a gender rather than class split. ${ }^{87}$ Whilst nurses were deferential to doctors, there is little evidence to suggest that they considered either themselves or the work that they did as subordinate to medicine. Even deference reduced as nurses gained the professional and personal confidence that came with active service. ${ }^{88}$ Nor is there evidence that they saw the delegation of tasks previously considered 'medical' as an indication of their subordination. Rather, they greeted with enthusiasm the implication that they were now seen as worthy and capable colleagues; this perhaps especially when sometimes the nurses transfused patients and sometimes the medical staff did. ${ }^{89}$ If work was interchangeable, it could not be subordinate.

During the First World War research into shock and haemorrhage led to developments in blood transfusions, but these involved highly complex and time-consuming techniques. ${ }^{90}$ By 1918 , although 
methods for storing whole blood had been developed, these were too late to be of benefit to most soldiers. ${ }^{91}$ The understanding of blood grouping was embryonic and, according to Carden-Coyne, there were only a few units that had the expertise to carry out the process. ${ }^{92}$ Furthermore, the instructions that most medical officers had been given in respect of the provision of blood transfusions were inadequate. ${ }^{93}$ Given the potential dangers of the transfusion procedure, it required the active participation and supervision of medical staff, with the support of nursing sisters and orderlies. By the time of the Spanish Civil War, 'great strides' had been made in the storage and preservation of blood for transfusion, enabling nurses and doctors to treat shock quickly and with good effect. However, the technologies, still in their infancy, meant that medical and nursing staff continued to provide direct transfusions, sometimes acting as donors themselves. This created the additional hazard that often too much blood was taken from these essential workers, who then needed periods of rest and recuperation themselves. ${ }^{94}$

Cynthia Toman argues that as blood transfusion work was delegated to nurses in the Second World War, it lost its place as a prestigious medical technology and became simply another job for the nursing staff. ${ }^{95}$ The delegation of medical tasks to nurses as the work becomes commonplace and mundane exemplifies Margaret and Patrice Higonnet's 'double helix' in which women are always subordinated and 'other'. When work is handed to women, not only is it because men no longer want it, but it is concurrently devalued because it now belongs to women. ${ }^{96}$ However, this is perhaps too simplistic or rigid a way to understand the expansion of nursing work and the delegation of what was once medical work to nurses. ${ }^{97}$

The great changes in transfusion technology between the First and Second World Wars meant that far more people could benefit from blood transfusion therapy and the therapy itself was no longer experimental. Sister D.M. Long wrote of the life-saving benefits of rapid transfusion that could now be given with 'no fuss'.$^{98}$ Once blood transfusions became something from which people expected to benefit and did not carry the risks of experimental medicine, in order to prevent it being a dehumanising technology the apparatus needed a human buffer. ${ }^{99}$ Thus the Second World War nurse not only made the technology possible but was the human face that enabled 
the patient to accept it. ${ }^{100}$ That is not to argue that the work had not become mundane to the medical officers who wanted to pass it on, but that there were also positive reasons for nurses to take on such work. The reassignment of blood transfusion care was arguably a natural progression as it moved from an experimental procedure that demanded medical expertise in the First World War, to a procedure that demanded the close monitoring of both technology and patient, both of which came and continue to be part of nursing, rather than medicine. It was not only that the medical profession delegated what had become simple work to nurses, but that blood transfusion had now become nursing work because its nature had changed.

The organisation of the British Blood Transfusion Service in 1938, shortly after the Munich Treaty, was to give the British Army a significant advantage over all other nations. ${ }^{101}$ It meant that safe, whole blood could be accessed quickly. The Americans had discovered in 1939 that unfiltered blood plasma was a useful substitute for whole blood, and continued to use it, often in place of whole blood. However, it was not as effective as whole blood in treating shock. On 5 October 1939, the Transfusion and Surgical Research Laboratory left for France. This laboratory was disbanded after the evacuation from Dunkirk in the summer of 1940, after which the British Transfusion Unit was established. ${ }^{102}$ In 1941, whilst undertaking her training, Emily Soper was allocated to join her hospital's transfusion unit:

We had a sister and staff nurse came from what was called the Civil Defence Unit and surprise, surprise, I was made their junior. So when the siren went off, we had to report to our, er, little quarters that were allotted to us, so we had to be ready, but fortunately again, we were not required to use our blood transfusion expertise on any casualties, but we were delegated to help our doctors, if they needed any help in the hospital. ${ }^{103}$

Importantly, with such a system in place in civilian practice, the military medical authorities were able to transfer knowledge rapidly into the field. By the spring of 1940, it was acknowledged that all medical officers, nurses and orderlies would have to understand the essentials of storing, preserving and administering blood transfusions for shock. It was no longer work for a few specialist units; the technology and clinical practice requirements meant that blood transfusions were transformed from a complex, medical task to 
essential therapy. ${ }^{104}$ C.A. Wells, an honorary surgeon at the Royal Liverpool Hospital, wrote in the Nursing Times in July 1945 that 'first bottle of blood I ever saw in a refrigerator was in the Meath Hospital in Dublin in 1939, I do not care to think how many I have seen since then!' ${ }^{105}$ In April 1942, a Nursing Times editorial reflected on wartime advances in medicine and surgery, commenting on the great change in the provision in blood transfusion: 'whereas before the war it would be two hours on average from the time the telephone rang in his [the doctor's] house to the time the needle was in the vein, to-day he could be starting the infusion within 20 minutes from the first tinkle of the bell'. ${ }^{106}$

In October 1944, Morris was working in a hospital set up in a convent near Louvain. Despite this not being particularly close to the front line, there was clearly a more collaborative way of working in which inter-professional expectations of practice were blurred. Thus, the nurses engaged in expanded areas of practice and the medical staff would help with the more nursing-type patient care of settling men into bed. They took convoy after convoy, some from CCSs near Nijmegen and others from a hospital near Arnhem:

Some were given plasma at once, others blood transfusions as soon as we
could identify the group (We have a small blood bank here) ... Have just
crawled off duty at 2 a.m. The patients are cleaned up, undressed (we had
to cut off their clothing) and in bed. There are six blood transfusions and
13 blood plasmas 'on the go'. Hope Connie can manage for the rest of the
night. She has two good orderlies. ${ }^{107}$

As the military medical services responded to the needs of a mobile war in which men could be treated much closer to the front, hospitals and CCSs were increasingly supported by independent blood transfusion units. ${ }^{108}$ One nursing sister noted that 'Blood transfusion and resuscitation service are splendidly organised especially in the forward areas'. This was particularly vital, since 'Gun shot wounds of abdomen are received into warm beds, a blood transfusion given at once and treatment for shock carried out. ${ }^{109}$ Sister E.L. L'Estrainge also noted the importance of the blood transfusion unit running independently from theatre. ${ }^{110}$ Given that all the casualties were exhausted and needed blood, this separate service could provide blood as necessary without removing the surgeon, theatre sister or 


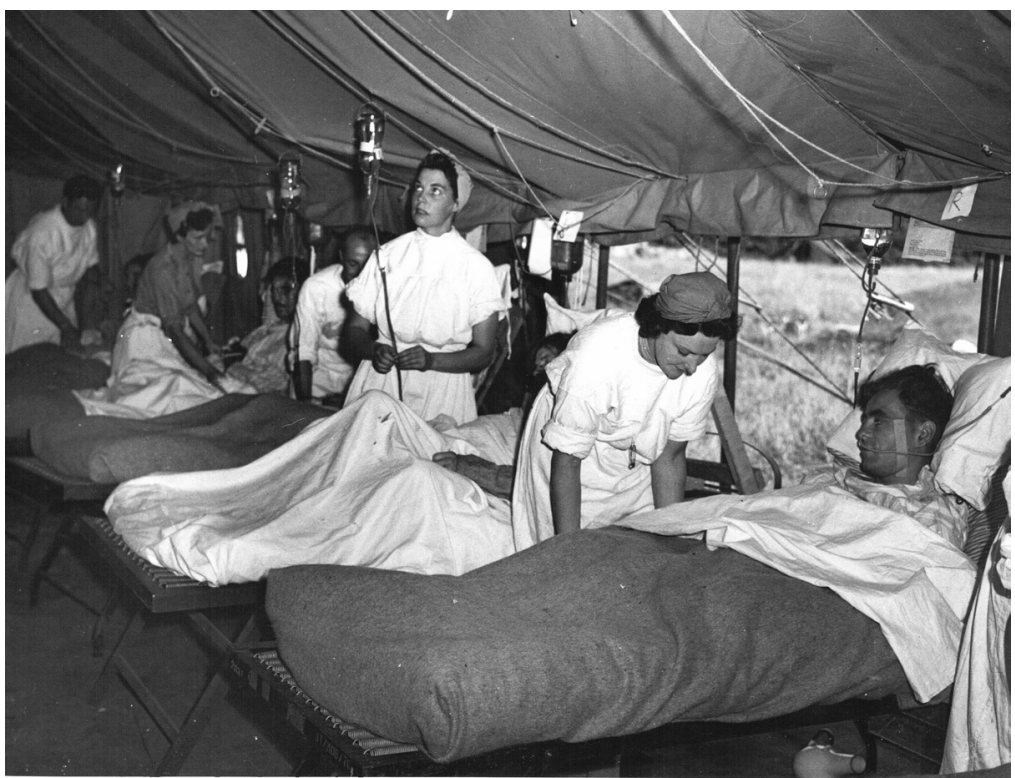

9 Nurses and patients in a field hospital. This image shows us the nurse's central role in blood transfusions. It is also worth noting the dramatic alterations in the uniform worn in comparison with the image of Nell Jarrett as a student nurse in figure 1. The nursing sister in this image of a field hospital in northern Europe is not restricted by either uniform or profession boundaries.

orderlies from the operating table. This was not the case in all situations. The hospital ship the Llandovery Castle collected its blood from Alexandria for each journey. The blood then became the responsibility of the surgeon, the trained orderly and the theatre sister. ${ }^{111}$

In whatever manner a particular blood transfusion system was organised on active service overseas, accountability was invariably cross-professional. The medical military authorities appreciated that 'blood work' was now an essential part of war medical services and needed support and collegiality to ensure that blood was stored and administered safely and efficiently. Unlike some other practices, blood work remained part of the lexicon of nursing duties postwar. ${ }^{112}$ Alongside nurses' participation in ever more complex wound care, it was clearly not a cause of inter-professional angst. However, 
there were other roles that were handed to nurses only 'for the duration' and only because of the extreme challenges of the war. Possibly the most controversial expanded role was that of nurses in anaesthetics. ${ }^{113}$

\section{The nurse-anaesthetist}

Between 1940 and 1942 a series of letters, many verging on the vitriolic, appeared in the British Medical Journal in relation to nurseanaesthetists. All were written by medical staff, none of whom appear to have been on active service overseas. On 28 September 1940, F.B. Parsons forwarded to the British Medical Journal a letter from medical staff of Addenbrooke's Hospital in Cambridge to the Association of Anaesthetists. In the letter they argued that 'with the outbreak of war five out of the eight honorary anaesthetists to the hospital were mobilised and left the district'. ${ }^{114}$ Since that time, the hospital had relied on the remaining three and increasingly junior and inexperienced medical officers to undertake anaesthetic duties, whilst the numbers of patients within the hospital rose. This, they felt, was unsustainable. The answer was to train nurses 'who had held the post of sister in a ward or operating theatre' to give anaesthetics. ${ }^{115}$ They would not supplant honorary anaesthetists, but would support the work of their colleagues in the operating theatres and, therefore, their patients.

The decision caused uproar. Nurses had been employed to act as anaesthetists by the British military on active service overseas in the First World War, but the practice had ceased in the aftermath of that earlier conflict. ${ }^{116}$ The Americans had continued to use nurseanaesthetists in the inter-war period and, according to Parsons, there were a number of British medical officers who, having worked with these nurses, were impressed by the service that they were able to provide. ${ }^{117}$ This did not assuage the anger of several correspondents to the British Medical Journal. A.M. Barford's letter, published on 5 October 1940, stated that 'the employment for this can be no other than a retrograde step ... I hope I shall never be a patient there, and I venture to say that each one of them [medical staff] would not wish a nurse to give him an anaesthetic.'118 W. Stanley-Sykes wrote of nurse-anaesthetists as being the 'bane of the second-rate American medical school' and praised the Canadians for outlawing the practice. ${ }^{119}$ Despite such antagonism to the idea of nurse-anaesthetists, 
there was a caveat to the correspondence from one medical man, that although nurses should not replace medically trained anaesthetists, they could perhaps give anaesthetics for 'minor surgical work'. ${ }^{120}$ What constituted 'minor' or major surgery on active service overseas was meaningless. Army nurses shifted the boundaries of their surgical practice as the exigencies of war demanded, and neither they nor their medical colleagues showed any of the professional anxieties of their counterparts on home soil.

After being shipwrecked on the SS Kuala, following the escape from Singapore in February 1942, Sister Edith Stevenson and her fellow passengers, found themselves island-hopping to avoid detection by the Japanese:

We knew those who had infected wounds would die and there was one case of gangrene needing amputation ... One other nurse and myself had been trained in operating theatre work, we knew the procedures but we had neither the instruments or anaesthetic.

One morning as if in answer to a prayer, a doctor Kirkwood arrived. What a relief to see him and his two orderlies. They had left Singapore after the Japanese invasion, travelling in a small motor-boat, they flew the Red Cross Flag and the Japanese allowed them safe passage. The doctor decided to amputate the leg as soon as we could make preparations. He had ether and chloroform and a few instruments. Strangely enough, he had no scissors, I was glad I had mine. We had no steriliser, so I found an empty kerosene tin and boiled the instruments in this over a charcoal brasier [sic], it was all very unorthodox. Doctor had some dressings and when all was ready we began. We were in the open air. Doctor started the anaesthetic and then handed over to his orderly whilst he began the operation. We amputated the leg and were just about ready to stitch up the flap of skin round the stump when the orderly flopped to the ground in a faint. The smell of the anaesthetic, together with an empty stomach proved too much for him. I took over the anaesthetic and doctor finished the stitching. The second orderly attended to his colleague. ${ }^{121}$

Following the capture of the ship the Rangitane, a group of nursing sisters were amongst the only British military women during the whole war ${ }^{122}$ to be held in captivity by Germans. The German sailors appear to have been profoundly uncomfortable holding them as prisoners. Whilst the men were taken below deck, the nurses were placed in a 'wooden structure on deck'. The German sailors had been preparing to lock the door, but an appeal by the nurses not to do so 
was accepted and 'we were left with guards after a drink of good hot coffee with sugar and milk'. ${ }^{123}$ The nurses, aware of the levels of illness and injury on board, sent to the German ship's doctor to ask if they could help:

Very quickly we were in his surgery ... The doctor gave the anaesthetics and then left Sister to keep the patient under, carefully explaining that nurses did not do that work in Germany. 'Nor in England' we answered him. When we got there he was just finishing inspecting the wounds, and, with our help was able to begin operating on the serious cases at once. ${ }^{124}$

Evelyn Cottrell, a nursing sister with the Spears Unit, ${ }^{125}$ was part of the contingent of nurses at the battle of Monte Cassino:

That was a very gruesome time, we had so many casualties, errm, so many casualties brought to us that they were all laid out the length of this room in rows and the colonel and the other doctors went round and the ones they thought they could save, they worked on, and the ones they, they couldn't do anything for, they hadn't time to do anything for and we used to dig out bits of shrapnel and err errm give blood all the time, we were always giving blood transfusions and err salines and things like that and we did a lot of minor surgery really with err, well with shrapnel bits and things and we didn't sleep, we just worked day and night and the colonel operated and operated day and night and had sort of an hour's sleep and off again and they were working like mad and a lot of people died, but a lot of people he saved, that wouldn't have been saved if they'd had to go back any further. ${ }^{126}$

These three separate and quite different accounts are critical for demonstrating the very different attitudes of doctors and nurses on active service to their perhaps more conservative colleagues in Britain. First, the admission by Stevenson that, had she had instruments and a means of anaesthesia, she and her nurse colleague would have operated on the severely injured man themselves suggests a willingness to ignore professionally held beliefs about what constituted nursing or medical work. Second, none of the incidents created any anxieties between either the medical practitioners or the nursing staff; all seemingly worked to the conviction that professional boundaries should not be maintained for the sake of the injured patients. Third, it was the male orderly who fainted, not the female nurse. Although the multiple gender contradictions that arose in the Second World War remained a source of concern for those keen to preserve the status quo, episodes like these identify the 
vital importance that such inter-professional concerns were ignored and, perhaps more pertinently, that they were no longer deemed appropriate. On active service overseas, British nursing sisters and their medical colleagues clearly believed it was the nurses' duty to expand their roles, despite professional and gendered notions, and that the most important person in the equation was the patient, not the nurse and not the doctor.

Thus far in this chapter the focus has been on duties that extended the province of nurses' work, such as their increasing responsibility for complex wounds, and on work that was an expansion of the nursing role into what had been previously considered medical work, for example, blood transfusions and the participation of nursing staff in anaesthetics. There was, however, one area of practice that would necessitate collaborative working, that required both professions to learn together almost from the beginning, and that did not enter the lexicon of medical work until 1942 - penicillin.

\section{New work: 'The new wonder drug Penicillin'}

Penicillin was made available to military patients in 1943 and was arguably the 'most significant achievement of the Second World War science and technology'. ${ }^{127}$ It was also a critical intervention for nurses, despite some initial fears. Prior to its development, often the only way to save a patient's life was through careful, meticulous and time-consuming nursing. Once penicillin became available it was as if nursing had 'gone out of the window'. ${ }^{128}$ Since their discovery and production in 1935, the sulphonamide drugs that were the precursors to penicillin had proved highly useful chemotherapeutic agents for the inhibition of certain bacteria. Sulphanilamide was effective against streptococcal infections, sulphapyridine against pneumococcal infections, gonorrhoea and meningitis, and sulphaguanidine successfully treated some cases of dysentery. ${ }^{129}$

However, a number of problems with the sulphonamides meant that they were not the ideal drug therapies. For many patients they led to nausea and vomiting, and for others, depression, dizziness and headaches were also common. By 1943 a paper appeared in the medical press alerting doctors to the possibility of allergic reactions to the sulpha drugs. ${ }^{130}$ More serious, but not as common, were 
the side-effects of agranulocytosis and haemolytic anaemia. In the former, reduced white cell counts were noted that led to ulceration of the mouth and throat and a general deterioration in the patient's condition. The latter manifested as jaundice and haemoglobinuria. ${ }^{131}$ According to C.M. Fletcher of the Radcliffe Infirmary at Oxford, whilst the sulpha drugs had 'revolutionized many parts of medicine', their potentially 'severely poisonous effects' meant that 'no one could claim that they were ideal'. ${ }^{132}$ Importantly, penicillin could cure staphylococcus infections which the sulpha drugs could not. Furthermore, its safety was believed in absolutely, ${ }^{133}$ and any early problems were blamed on the production process rather than on the drug itself. ${ }^{134}$ It was not until 1945 that a paper appeared in the British Medical Journal informing readers of the possibility of allergic reactions, warning that 'it is understood that the above is the only occurrence of a reaction of this type [eczema and discharge] to penicillin therapy in more than 30,000 cases treated in the B.L.A. [British Liberation Army]'. ${ }^{135}$ Despite such ardent confidence in the marvel of penicillin, in its very early days there were some substantial problems. Florey and his team struggled to produce it in sufficient quantities. Moreover, penicillin was so rapidly excreted by the kidneys that in the very early experimental uses on patients in England, staff had to collect the patient's urine and extract the penicillin to provide further doses. ${ }^{136}$ From these very early experiments, it was realised that the co-operation and interest of the nursing staff was essential. ${ }^{137}$

Although penicillin was available from 1943, as one report in the British Journal of Nursing maintained, its manufacture even in minute quantities is so tedious and lengthy that the entire output is reserved for the Services'. ${ }^{138}$ One effect of this, which caused consternation in the press and amongst practitioners in the field, was that its use for the military meant that it was available for German POWs ${ }^{139}$ but not British civilians, even those whose injuries were war related. According to a brief report in the British Medical Journal, 'the Government was required by the Geneva Convention to care for wounded prisoners of war, without distinction of nationality, equally with our own personnel', and there was just not enough available to treat both the military and civilians. ${ }^{140}$ Despite this pronouncement, there were occasional experiments with penicillin on members of the 
civilian population, although it was used only as a "corpse-raising drug," i.e., not being tried until all else has failed'. ${ }^{141}$

In December 1943, The Lancet reported that Florey and his team had been in North Africa since the summer, testing the efficacy of penicillin. They demonstrated that it was effective on all soft-tissue wounds, including septic wounds, and that a combatant infected with gonorrhoea could be treated and returned to the front within three days. ${ }^{142}$ By 1944, it was more generally used in war zones, but not without its difficulties for both the nursing staff and the patients themselves. According to much of the analysis in the nursing and medical press, it could not be given orally and its rapid excretion meant that it needed to be given as intramuscular injections at three-hourly intervals. ${ }^{143}$ The injections were very painful, repetitive and interrupted the combatant patient's much-needed sleep. ${ }^{144}$ Alternatively it could be given as a constant intravenous infusion, ${ }^{145}$ but this required very careful nursing attention and a medical presence to site the infusion cannula, both of which could be difficult on active service overseas. In February 1945, Sister M.K.I. Harpin wrote to Dame Katharine Jones maintaining that a method of administering penicillin orally to a patient with pneumonia had been used and had worked, although it still required a three-hourly intervention and could not have been pleasant for the patient:

A level teaspoonful of alkali - which in this case was magnesium trisilicate or sodium bicarbonate, was taken dissolved in a quarter of a pint of milk. Ten minutes later the Penicillin beaten up with an egg, and with a little milk and glucose added was given. This procedure was repeated three hourly, each dose being followed by a mouth wash. ${ }^{146}$

For those nurses and doctors seeing penicillin in use in the early days, it was like a miracle. Morris described it as 'The new wonder drug Penicillin', which, she wrote, was 'a great help in the fight to save the lives of young men like Len. This is the first time I have seen the antibiotic in action ... It seems particularly good in preventing gangrene infections in gunshot wounds. ${ }^{147}$ However, in October 1944 Morris had another patient whose infected stump did not appear to respond to penicillin. ${ }^{148}$ Unfortunately she does not follow up this case in her diary, so it is not known whether the treatment was eventually successful or not. Bolton's war memoir records the first 
time she saw penicillin used, sometime in the spring of 1944, whilst nursing in India:

Major Niblock and Joan Inman were there, dressed as for an operation in gauze masks, sterile gowns and rubber gloves. The major was drawing some yellow liquid into a large syringe. He held it up to the light, saying, 'This is the new drug, which has just arrived. It is called Penicillin and we are going to try it on this patient.' After carefully cleaning the skin, he injected the drug into a muscle ... Just before going off duty we visited the ward once more and were astonished at the improved state of the wound. There was no longer any doubt - the infection was receding. After five days of threehourly injections the solider was able to walk with the help of a stick, finally making a complete recovery. ${ }^{149}$

Bolton does not say who administered the three-hourly injections to this man, but it is unlikely that it was the doctor. Other nurses across all the war zones of the globe described the arduous and time-consuming nature of penicillin administration. Gertrude Cooper, a Queen Alexandra's Royal Naval Nursing Service Sister, described the work entailed in administering it intramuscularly: 'the penicillin was um, solid - it floats sufficiently to draw it up into a syringe already loaded with um - saline, and when this mixture was mixed it was given in the buttock'. ${ }^{150}$ According to Dyer, 'it had to be given three hourly day and night which meant a constant flow of work preparing, sterilising, and giving injections and no sooner had we completed one round of injections to the various patients when it was time to start the next'. ${ }^{151}$ Salter's testimony corroborates the elaborate and time-consuming work, administered as it was 'at three hourly intervals under full aseptic conditions'. ${ }^{152}$ Even when the orders for strict asepsis were abandoned, the need for the drug to be given three hourly meant that the work remained time consuming. It would not have been possible, therefore, for the medical officers to continue to be the professionals who administered it. Nevertheless, their continued interest in its usage and the rapid involvement of the nursing staff in its administration suggest growing acknowledgement of the professional abilities and trustworthiness of nursing sisters. ${ }^{153}$ Critically, penicillin if administered early in the infection, whether that infection was caused by illness or injury, could return men very rapidly to war. ${ }^{154}$ The need for nurses to administer penicillin thus legitimated their place in volatile, front-line duty. Nursing sisters 
were therefore able to 'parlay' their skills with this new technology to be included in forward areas.

The whole ethos of penicillin in the Second World War seems to have been one of inter-professional participation. ${ }^{155}$ PMRAFNS Sister Joan Peake recalled that the chemists in the pharmacy at her Cairo hospital made 'primitive penicillin by growing a mould on jam, pots of jam, used to sterilise it and send it up to use and we used to use it on desert sores, with exceptionally good results'. ${ }^{156}$ By December 1943, the British Medical Journal was detailing that such practices were not supported: 'the Mediterranean Report urges strict control of supplies, with concentration in one theatre of operations, and gives no encouragement to the supporters of crude penicillin'. ${ }^{157}$ According to Cynthia Toman, having learnt about penicillin on active service overseas alongside their medical colleagues, Canadian nursing sisters returned to civilian practice in the post-war era and there played an important role in teaching medical staff about the drug. ${ }^{158}$ Such activity altered both gender and professional boundaries in a way that would have not been considered possible prior to the Second World War. There is no evidence in the personal testimonies of British nurses that this was mirrored in Britain. However, it is likely, given the close involvement of nursing sisters in all war zones in the preparation, administration and monitoring of penicillin, that they were called upon to train nurses and doctors who had not been on active service overseas in its use.

\section{Conclusion}

The constantly shifting requirements of war nursing prevented Army nurses from remaining in a professional comfort zone of accepted roles and regimes. The experience of living with uncertainty may have caused anxieties for some, but the active participation in new treatment modalities suggests that nurses who went to war were keen to move beyond the normal boundaries of nursing practice and many relished the opportunity to do so. The chapter has examined a range of surgical practices by way of a 'case study' of changing nursing roles. Whether they arose from traditional nursing work that was altered by the exigencies of war, were work that the over-stretched but now trusting medical staff passed on to nursing sisters or were roles that 
by reason of their novelty were developed by the medical and nursing staff as a team, the new responsibilities raised the nurses' sense of their professional ability.

Despite the increased confidence and autonomy in practice, the war was not the watershed for nursing that some have argued. ${ }^{159}$ Some of the extended, expanded and new work was, by the end of the war, enshrined into nursing practice; other work was reclaimed by and returned to medicine. The differentiations of these working practices, and the reasons why some were given gladly to the nurses, such as blood transfusion work, while other work was closely reguarded at the end of the war by medics, have been the subject of a number of texts. ${ }^{160}$ What was critical to the professional lives of British Army nurses who were posted overseas during the Second World War was that, despite the challenges inherent in the negotiations of work and gender boundaries, they were changed by them. For many, in the aftermath of war, a return to the stifled world of the British hospital nursing system was not possible, and many sought alternatives.

\section{Notes}

1 Brenda McBryde, A Nurse's War (Saffron Walden: Cakebread Publications, 1993), 57.

2 Joan E. Lynaugh and Julie Fairman, Critical Care Nursing: A History (Philadelphia, PA: University of Pennsylvania Press, 1998), 11.

3 Lucy Noakes, War and the British: Gender, Memory and National Identity (London: I.B. Tauris, 1998), 52.

4 Noakes, War and the British, 20-1.

5 War Office, 'No. 1 General Hospital Jan to December 1940' (23 April 1940), TNA WO 177/1092.

6 Cynthia Toman, An Officer and a Lady: Canadian Military Nursing and the Second World War (Vancouver: University of British Columbia Press, 2007), 57.

7 Cynthia Toman, 'Front lines and frontiers: War as legitimate work for nurses, 1939-1945', Social History 40, 79 (2007): 72.

8 Anonymous Sister (QAIMNS/R), 'The departure of the British Military Hospital, Marseilles', in Ada Harrison (ed.), Grey and Scarlet: Letters from the War Areas by Army Sisters on Active Service (London: Hodder and Stoughton, 1944), 21.

9 Mary Morris, 'The diary of a wartime nurse' (23 June 1944), 107, IWM 
Documents 4850; Mary Morris, A Very Private Diary: A Nurse in Wartime, ed. Carol Acton (London: Weidenfeld and Nicolson, 2014), 93.

10 Sister TANS, 'Experiences of an Army Sister in the Middle East', MMM QARANC uncatalogued archive, MEF memoirs.

11 Betty C. Parkin, Desert Nurse: A World War II Memoir (London: Robert Hale, 1990), 131.

12 Angela Bolton, The Maturing Sun: An Army Nurse in India 1942-45 (London: Headline, 1986), 195.

13 Anonymous Sister, 'Middle East and the hospital at Tobruk', in Ada Harrison (ed.), Grey and Scarlet: Letters From the War Areas by Army Sisters on Active Service (London: Hodder and Stoughton, 1944), 126; Geraldine Edge and Mary E. Johnston, Ships of Youth: The Experiences of Two Army Nursing Sisters on Board the Hospital Carrier Leinster (London: Hodder and Stoughton, 1945), 45.

14 Morris, 'The diary of a wartime nurse' (20 February 1945).

15 Esther Helen Audrey Luker ARRC, 'Diaries from 1940-45' (7 November 1940), IWM Documents 1274.

16 Luker 'Diaries' (20 December 1940)

17 Parkin, Desert Nurse, 115.

18 Catherine Arnold Hutchinson, 'My war and welcome to it', 112, IWM Documents 11950.

19 Joan Eileen Nicolson, oral history by Conrad Wood, 8 June 1991, IWM Sound Archive 12075.

20 Ana Carden-Coyne, The Politics of Wounds: Military Patients and Medical Power in the First World War (Oxford: Oxford University Press, 2014), $301-2$.

21 According to Anna Rogers, the New Zealand orderlies were initially highly circumspect about working under the authority of nursing sisters, having never worked under a woman before. However, Rogers argues, the orderlies were ultimately glad of the nursing sisters' expert knowledge of nursing matters to guide them. Anna Rogers, While You're Away: New Zealand Nurses at War, 1899-1948 (Auckland: Auckland University Press, 2003), 212. It is likely that this change in attitude was not quite as stark as Rogers maintains, and that there remained many male orderlies for whom the advent of nursing sisters into their masculine domain was an affront. However, the posting of nursing sisters to forward areas, including Mobile Dressing Stations, suggests that the benefit of expert female nurses outweighed any personal feelings. Rogers, While You're Away, 239.

22 Emma Newlands, Civilians into Soldiers: War, the Body and British Army Recruits, 1939-45 (Manchester: Manchester University Press, 2014), 131.

23 Toman, An Officer and a Lady, 118; Kevin Brown, Fighting Fit: Health, Medicine and War in the Twentieth Century (Stroud: The History Press, 2008, Kindle edition), loc. 3099. 
24 Julie Fairman and Patricia D'Antonio, 'Reimagining nursing's place in the history of clinical practice', Journal of the History of Medicine and Allied Health Sciences 63, 4 (2008): 444.

25 Toman, An Officer and a Lady, 64.

26 Margarete Sandelowski, 'Venous envy: The post-World War II debate over IV nursing', Advances in Nursing Science 22, 1 (1999): 52-62; Margarete Sandelowski, Devices and Desires: Gender, Technology and American Nursing (Chapel Hill, NC: University of North Carolina Press, 2000).

27 Apart from the tasks discussed in this chapter, other key therapies that became part of the nurses' lexicon of skills on active service overseas were monitoring of the effects of new psychotherapeutic treatment regimes and the microscopic diagnosis of malaria. For a detailed discussion of the war work of Hildegard Peplau, the pioneering mental health nurse, with psychologically damaged men, see especially, Barbara J. Callaway, Hildegard Peplau: Psychiatric Nurse of the Century (New York: Springer, 2002). Patricia Moody described the interest she gained from learning to read malaria slides: 'I am learning bacteriology and spend a fair amount of my spare time peering down a microscope searching blood slides looking for malarial parasites.' Sister Patricia Moody TANS, 'My dearest mums', 76 General Hospital, British North Africa Force (24 July 1943) RCN Archives, Edinburgh. Tropical disease diagnosis and treatment had become the province of the nurses, who appear to have taken to the new role with willingness. This work was time consuming, required precision in the timing of taking blood slides and placed the responsibility for reading the results of the slide with the nurses themselves. Toman, An Officer and a Lady, 134.

28 According to Ana Carden-Coyne, 'Blighty' was first used to describe Britain as home in the First World War. It originated in colonial India, 'belati' being the Hindustani word for 'home; foreign country'. The British then punned with 'blight'. Carden-Coyne, The Politics of Wounds, 71.

29 David Justham, “Those maggots - they did a wonderful job": The nurses' role in wound management in civilian hospitals during the Second World War', in Jane Brooks and Christine E. Hallett (eds), One Hundred Years of Nursing Wartime Practices, 1854-1953 (Manchester: Manchester University Press, 2015), 198. Testimonies from nursing sisters maintained that this disciplined training had supported the sublimation of the self into a 'nursing-self', thus enabling them to undertake dirty work and also work under the intense pressure needed for war nursing. For a detailed discussion of the benefits of the dehumanising and disciplined training of nurses, see Chapter 1 in this volume.

30 Michael Traynor, Maggie Boland and Niels Buus, 'Autonomy, evidence and intuition: Nurses and decision-making', Journal of Advanced Nursing 66, 7 (2010): 1584-91.

31 Justham, “Those maggots - they did a wonderful job"', 194. Although 
some nurses would not alter the round, depending on which wounds were clean or dirty, there were other hospitals in which they were expected to make such decisions. Justham, "Those maggots - they did a wonderful job"', 193.

32 Morris, 'The diary of a wartime nurse' (31 May 1940), 2; Morris, A Very Private Diary, 3.

33 Penny Salter, 'Long ago and far away: A distant memory': A diary, c. 19381970, 24-6, UK Centre for the History of Nursing (UKCHN), University of Manchester. See also IWM Documents 17649.

34 Mary Bond, Wartime Experiences from the Midnight Sun to Belsen (Cardigan: E.L. Jones and Son, 1994), 16.

35 Toman argues that this conveyor-belt 'care' that was a part of wartime nursing, exemplified 'dirty' work. It was mundane, physically dirty and repetitious. This understanding of body work which renders it low status and designated as women's work is developed in Jocalyn Lawler's Behind the Screens: Nursing, Somology and the Problem of the Body (Melbourne: Churchill Livingstone, 1991) and discussed with reference to nursing wartime work by Jane Brooks and Christine E. Hallett, 'Introduction: The practice of nursing and the exigencies of war', in Jane Brooks and Christine E. Hallett (eds), One Hundred Years of Wartime Nursing Practices, 1854-1953 (Manchester: Manchester University Press, 2015). However, there is no suggestion in any of the testimonies that the British nurses in the Second World War understood it that way, especially when left to the work without interference from authority. In fact, when Sister Agnes Morgan is left to face a convoy at her CCS in Europe, she described the excitement of working under 'real war-nursing' conditions and how they just 'got down to our endless stream of wounded men'. Agnes Kathleen Dunbar Morgan, 'My dearest mums', letter 57 (August 1943), CMF, 2. 'Still with the lamp: letters to my mother by an army nursing sister. Egypt - North Africa - Sicily - Italy, 1941-1944', IWM Documents 16686. As Julie Anderson acknowledges, improved transport technologies meant that men could access more complex treatment in mobile units. The increasing complexity of the treatments in turn meant that registered nurses were needed to care for the men, moving the nursing sisters ever closer to the battle lines. Julie Anderson, War, Disability and Rehabilitation in Britain: 'Soul of a Nation' (Manchester: Manchester University Press, 2011), 76.

36 J.R. Learmonth, 'The surgical nurse', in J.M. Mackintosh (ed.), Wartime Nurse: An Anthology of Ideas about the Care and Nursing of War Casualties (Edinburgh: Oliver and Boyd, 1940), 22.

37 Bruce M. Dick, 'Injuries and wounds of the chest', in J.M. Mackintosh (ed.), Wartime Nurse: An Anthology of Ideas about the Care and Nursing of War Casualties (Edinburgh: Oliver and Boyd, 1940), 85.

38 John Elam, 'Anaesthesia in war-time', The Lancet (15 April 1939): 906. 
39 Morris, 'The diary of a wartime nurse' (7 September 1944), 130; Morris, A Very Private Diary, 112.

40 Carden-Coyne, The Politics of Wounds,191.

41 E.L. L'Estrainge, 'Work and experiences in the Middle East, 1941-1942', MMM QARANC uncatalogued archive, MEF memoirs.

42 W.H.C. Romanis, 'Amputation in war time', Nursing Times (15 June 1940): 266.

43 Sister TANS, 'Experiences of an Army Sister in the Middle East'.

44 H.B. Woods, 'Treatment of severe war-time burns', Nursing Times (5 November 1943): 833.

45 Morris, 'The diary of a wartime nurse' (5 October 1944), 144; Morris, A Very Private Diary, 126-7.

46 T.B. Layton, 'Transport of wounded: Surgical aspects', The Lancet (23 March 1940): 537-40.

47 Hutchinson, 'My war and welcome to it', 40.

48 Dorothy B. Doughty, 'History of ostomy surgery', Journal of Wound Ostomy Continence Nursing 35, 1 (2008): 34-8.

49 The Feminine Touch. Director, Pat Jackson, written by Iain MacCormick. Released 27 March 1956, Ealing Studios. The film follows the lives of five student nurses in the young NHS. http://www.imdb.com/title/tt0050428/ [accessed 28 September 2016].

50 Julia Hallam identifies this film as one in which the nurse's role as patient carer is subordinated to nurse as the one who cares for the male doctor, thereby playing into post-war tropes of a domesticity. Nevertheless, as Hallam argues, 'the deep happiness to be found in nursing is that of being in service'. Julia Hallam, Nursing the Image: Media, Culture and Professional Identity (London: Routledge, 2000), 61.

51 Hutchinson, 'My war and welcome to it', 39.

52 McBryde, A Nurse's War, 58.

53 Sister N.M. Liddiard, 'Surgical nursing in wartime' (3 September 1945), MMM QARANC uncatalogued archive.

54 Cecil P.G. Wakeley, 'The treatment of war burns', Nursing Times (11 December 1941): 819.

55 R.G. Henderson, 'Treatment of incendiary bomb burns', Nursing Mirror (6 July 1940): 325.

56 Anonymous, 'Editorial: Tannic acid "is out", Nursing Mirror and Midwives Journal (23 November 1940):171. For a detailed discussion of the debates about the use of tannic acid in the early 1940s, see Brown, Fighting Fit, loc. 2318-3244.

57 Anonymous, 'Editorial: Tannic acid “is out”, 171. According to Mayhew, it was McIndoe himself who secured the banning of tannic acid. Emily Mayhew, The Reconstruction of Warriors: Archibald McIndoe, The Royal Air Force and the Guinea Pig Club (Barnsley: Greenhill Books, 2010, Kindle edition), loc. 
900-921. Harrison maintains that a study by the Medical Research Council that highlighted the liver damage that it caused ultimately led to its demise. Mark Harrison, Medicine and Victory: British Military Medicine in the Second World War (Oxford: Oxford University Press, 2004), 157.

58 Morris, 'The diary of a wartime nurse' (1 June 1940), 2; Morris, A Very Private Diary, 4.

59 John Bunyan, 'A preliminary report on treatment of wounds and burns by the envelope method', Nursing Mirror 72 (22 February 1941): supplement, ii-iii.

60 Anonymous Nursing Sister, 'The adventures of a nursing officer (QAIMNS) 1939-45 and sidelights of some tropical diseases, also battle wounds', MMM QARANC uncatalogued archive, MEF memoirs.

61 Anonymous QAIMNS Reserve, 'Gibraltar, January 1940 to January 1942', in Ada Harrison (ed.), Grey and Scarlet: Letters from the War Areas by Army Sisters on Active Service (London: Hodder and Stoughton, 1944), 136-7.

$62 \mathrm{~V}$. Shennan, 'Notes on the treatment of burns with sulphonamide "emulsion” in a base hospital M.E.F.', MMM QARANC uncatalogued archive.

63 Stanford Cade, 'Burns in the Royal Air Force', Medical Training Establishment and Dept Royal Air Force Journal 1 (1941): 2.

64 Emergency Medical Services, Ministry of Health, 'Memorandum: The treatment of burns', Nursing Times (5 April 1941): 242.

65 Penny Starns, Nurses at War: Women on the Frontline, 1939-45 (Stroud: Sutton Publishing, 2000), 41.

66 Archibald H. McIndoe, 'Saline baths treatment for burns', Nursing Mirror (18 July 1942): i.

67 McIndoe, 'Saline baths treatment for burns', ii.

68 Bolton, The Maturing Sun, 168.

69 Ann Radloff, 'Going to Gooseberry Beach: Travels and adventures of a nursing sister', 5, IWM 147.

70 Betty Evans oral history interview by Jane Brooks via the telephone on 10 January 2014.

71 Edge and Johnston, Ships of Youth, 118.

72 Norman J. Logie, 'Treatment of burns at Tobruk', The Lancet (15 May 1943): 609 .

73 Logie, 'Treatment of burns at Tobruk', 611.

74 Evans, oral history, 10 January 2014.

75 Philip Mitchiner, 'Modern methods of treating war burns', Nursing Mirror (10 May 1943): 23.

76 Woods, 'Treatment of severe war-time burns', 821.

77 Woods, 'Treatment of severe war-time burns', 827.

78 Evans, oral history, 10 January 2014.

79 Anonymous Nursing Sister, 'The Anzio Beachhead', MMM QARANC uncatalogued archive, CMF file. 
80 Anonymous, 'The technique of blood transfusion', Nursing Mirror (2 September 1939): 764.

81 P.M. Dyer, 'When life was grey and scarlet: A recollection of life as an Army Nursing Sister', 71, MMM QARANC/PE/1/151/DYER Box 8.

82 June Hamilton, oral history interview by Jane Brooks at her home in the South of England, 19 October 2011.

83 Sandelowski, 'Venous envy', 57.

84 McBryde, A Nurse's War, 86.

85 Toman, An Officer and a Lady, 126.

86 Harold Smith's assertion that Arthur Marwick was mistaken when he assumed that the war altered the position of women is in many ways borne out in the reality that women in healthcare were maintained in nursing rather than encouraged to enter the medical profession. However, Smith's notion that this lack of opportunity did not manifest itself in an altered consciousness of women is more difficult to substantiate. Women may have continued to be nurses next to the undoubtedly academically, financially and socially superior medical profession, but the war certainly altered the way they understood themselves in the medical team. Harold Smith, 'The effect of the war on the status of women', in Harold Smith (ed.), War and Social Change: British Society in the Second World War (Manchester: Manchester University Press, 1986), 217.

87 Agnes Morgan's brother was a medical doctor, P.M. Dyer's brother was an officer in the RAF.

88 Mary Morris wrote humorously and without deference of the arrival of a gynaecologist as the new medical officer to their hospital in August 1944: 'there is bound to be a certain amount of culture shock for him here!' Morris, 'The diary of a wartime nurse' (31 August 1944), 128. Such statements leave the reader with the genuine impression that those already experienced in battle conditions believed themselves to be superior in knowledge to newly posted colleagues, whatever their professional background. See also Morris, A Very Private Diary, 110. Cynthia Toman argues that the Canadian nurses experienced a similar rise in confidence as they were trusted to take on increasingly experimental, innovative and complex work. Toman, 'Front lines and frontiers', 66.

89 Geraldine Edge and Mary Johnston note that when they landed in Italy in 1943 , 'the anaesthetist and surgeon would go to the wards and give plasma or a blood transfusion'. Edge and Johnston, Ships of Youth, 33.

90 Carden-Coyne, The Politics of Wounds, 146; Christine E. Hallett, Containing Trauma: Nursing Work in the First World War (Manchester: Manchester University Press, 2009), 31-2. Hallett describes the two most popular techniques, firstly the one favoured by Canadian physician Lawrence Bruce Robertson, in which the doctor withdrew blood from the donor in a canula and then injected into the recipient via another canula. The other technique 
involved blood being allowed to flow freely directly from the donor into the recipient.

91 Carden-Coyne, The Politics of Wounds, 147; Hallett, Containing Trauma, 32.

92 Carden-Coyne, The Politics of Wounds, 156.

93 Ian Whitehead, 'The British medical officer on the Western Front', in Roger Cooter, Mark Harrison and Steve Sturdy (eds), Medicine and Modern Warfare (Amsterdam, Atlanta: Rodopi, 1999), 171.

94 Angela Jackson, 'Blood and guts: Nursing with the International Brigades in the Spanish Civil War, 1936-39', in Jane Brooks and Christine E. Hallett (eds), One Hundred Years of Nursing Wartime Practices, 1854-1953 (Manchester: Manchester University Press, 2015), 172.

95 Cynthia Toman, 'Blood work: Canadian nursing and blood transfusion, 1942-1990', Nursing History Review 9 (2001): 52.

96 Margaret R. Higonnet and Patrice L.-R. Higonnet, 'The double helix', in Margaret Randolph Higonnet, Jane Jenson, Sonya Michel and Margaret Collins Weitz (eds), Behind the Lines: Gender and the Two World Wars (New Haven, CT: Yale University Press, 1987).

97 Penny Summerfield, 'Gender and war in the twentieth century', The International History Review 19, 1 (1997): 4.

98 D.M. Long, 'Advances in surgical nursing, with special reference to work in C.C.S. etc.', 1, MMM QARACNC uncatalogued archive.

99 Toman, An Officer and a Lady, 143.

100 Julie Fairman, 'Alterative visions: the nurse-technology relationship in the context of the history of technology', Nursing History Review 6 (1998): 137.

101 Mark Harrison, Medicine and Victory: British Military Medicine in the Second World War (Oxford: Oxford University Press, 2004), 116. Contrary to this belief, however, it is apparent that in some circumstances plasma continued to be used for shock, instead of blood. On 23 June 1944, Mary Morris wrote in her diary, 'The ones who were shocked through loss of blood were put on a plasma intravenous drip'. Morris, 'The diary of a wartime nurse' (23 June 1944), 108; Morris, A Very Private Diary, 93.

102 F.A.E. Crew, '25. The Field Transfusion Unit: United Kingdom - the Army', in Arthur Salusbury MacNalty and W. Franklin Mellor (eds), Medical Services in War: The Principal Medical Lessons of the Second World War (London: HMSO, 1968), 123.

103 Emily Soper, oral history interview via telephone by Jane Brooks, 6 September 2013.

104 Harrison, Medicine and Victory, 56; Brown, Fighting Fit, loc. 3262.

105 C.A. Wells, 'Post-war pattern: War-time advances in surgery', Nursing Times (9 June 1945): 369.

106 Anonymous, 'Editorial: War-time advances and antiseptics', Nursing Times (11 April 1942): 237. 
107 Morris, 'The diary of a wartime nurse' (4 October 1944), 143; Morris (Acton ed.), A Very Private Diary, 125.

108 Harrison, Medicine and Victory, 115.

109 Anonymous Nursing Sister, 'The adventures of a nursing officer', 14.

110 L'Estrainge, 'Work and experiences in the Middle East, 1941-1942'.

111 Anonymous, 'In step with the QAs. 8. - Hospital ship (Part I), Nursing Times (30 September 1944): 678. For a more detailed discussion of the involvement of orderlies in blood transfusion work see 'David Proctor, RAMC, orderly, 1944-47’, in Barbara Mortimer, Sisters: Extraordinary True-Life Stories from Nurses in World War Two (London: Hutchinson, 2012), 198-9. In 1947, David Proctor entered St Mary's Hospital, Highgate, London to train as a State Registered Nurse. Whilst it was still unusual for men to enter general nursing at this time, men were coming out of the forces wanting to train as nurses and therefore a small but significant body of men in general nursing began to emerge. Mortimer, Sisters, 299.

112 Toman, 'Blood work'.

113 Nurse anaesthetists had been trained the First World War by Britain, the Dominions and the USA. Although, because of the antipathy of the Australian Director of Medical Services towards women being posted to forward areas, Australian nurses were never allowed to actually practise, all the other nations used nurses to provide ether anaesthetics. At the end of the war, only the USA continued to use nurses in this role. Hallett, Containing Trauma, 99-100; Carden-Coyne, The Politics of Wounds, 76.

114 F.B. Parsons, 'Nurse anaesthetists', British Medical Journal (28 September 1940): 429.

115 Parsons, 'Nurse anaesthetists', 429.

116 Hallett, Containing Trauma, 99.

117 Parsons, 'Nurse anaesthetists', 429.

118 A.M. Barford, 'Nurse anaesthetics', British Medical Journal (5 October 1940): 474.

119 W. Stanley-Sykes, 'Nurse anaesthetists', British Medical Journal (1 March 1941): 339.

120 Alan F. Goode, 'Correspondence', British Medical Journal (28 September 1940): 430.

121 Edith Stevenson, 'The last lap: Autobiography 1912-1986', 14-15. IWM LBY94/1636.

122 Whilst there may have been other incidences, this was the only one found during the research for this book.

123 Anonymous, 'Nursing adventure: The story of two nursing sisters returning on the Torpedoed "Rangitane”, Nursing Times (25 October 1942): 672.

124 Anonymous, 'Nursing adventure', 672.

125 The Spears Unit was accredited to the Free French Forces and under the 
command of Lady Spears, formerly Mary Borden, and Lady Hadfield. See Eric Taylor, Front-Line Nurse: British Nurses in World War II (London, Robert Hale, 1997), 39; Christine E. Hallett, Nurse Writers of the Great War (Manchester: Manchester University Press, 2016), 58.

126 Evelyn Alma Cottrell, Spears Unit, oral history interview by Lyn E. Smith, 9 July 1990, IWM Oral History Collection, Interview 12180.

127 Peter Neushul, 'Fighting research: Army participation in the clinical testing and mass production of penicillin during the Second World War', in Roger Cooter, Mark Harrison and Steve Sturdy (eds), War, Medicine and Modernity (Stroud: Sutton Publishing, 1998), 204. See also Harrison, Medicine and Victory; Mayhew, The Reconstruction of Warriors, loc. 436; Brown, Fighting Fit.

128 Winifred Hector, in Barbara Mortimer, Sisters: Extraordinary True-Life Stories from Nurses in World War Two (London: Hutchinson, 2012), 196. The notion that penicillin would reduce the need for nurses and might even put the profession in peril is also discussed in Starns, Nurses at War, in which Monica Baly is cited as stating, 'No longer was the doctor saying, "I can't do anything, but nursing will do a great deal". We had now got to the stage when it appeared as if nursing was not doing very much. The patients got better whether they were nursed or not.' Starns, Nurses at War, 72. See also Justham, "“Those maggots - they did a wonderful job”.

129 John F. Stokes, 'The present status of the sulphonamide drugs', Nursing Times (21 February 1942): 124; S.C. Turner, 'All in the day's work. III Nursing on a troopship', Nursing Times (17 January 1942): 76.

130 R.G. Park, 'Cutaneous hypersensitivity to sulphonamides: A report of 12 cases', The British Medical Journal 2, 4306 (17 July 1943): 69-72.

131 Stokes, 'The present status of the sulphonamide drugs', 125.

132 C.M. Fletcher, 'Penicillin: A recent advance in chemotherapy', Nursing Times (4 October 1941): 798.

133 Robert Bud, Penicillin: Triumph and Tragedy (Oxford: Oxford University Press, 2007), 105.

134 Bud, Penicillin: Triumph and Tragedy, 105.

135 W. Michie and H.W.C. Bailie, 'A case of penicillin reaction', The British Medical Journal 1, 4398 (21 April 1945): 554.

136 Fletcher, 'Penicillin: A recent advance in chemotherapy', 799.

137 Fletcher, 'Penicillin: A recent advance in chemotherapy', 800.

138 Anonymous, 'Penicillin saves wounded soldiers', The British Journal of Nursing (September 1943): 104. If the use of penicillin for military personnel only was the subject of some debate, its use for gonorrhoea and syphilis caused anger. As Kevin Brown argues, sexually transmitted infections were considered by some to be self-inflicted wounds and by many to be the result of unacceptable, licentious behaviour. Brown, Fighting Fit, loc. 3514. The numbers of troops affected by venereal disease have been given by Harrison 
in the Italian campaign as 51 per 1,000 in 1944 , rising to 71 per 1,000 in 1945. Harrison, Medicine and Victory, 102. Despite the moral objections to the use of penicillin for sexually transmitted infections, the benefit to the war effort was seen as paramount. Treatment with sulphonamides for gonorrhoea could take up to 25 days and over 40 for syphilis; with penicillin this was reduced to 24 hours and four to five days, respectively. Harrison, Medicine and Victory, 107; Anonymous, 'Penicillin in the field', 738. Given the sheer numbers of those affected it would not have been possible for nursing staff to have ignored its presence, or to have not been in professional contact with those who were infected. Yet discussions of the care proffered to troops with VD are noticeable by their absence in personal testimonies. This is probably a result of notions of acceptable knowledge and issues of propriety for the nursing sisters. The purpose of this book is to consider the nurses' work and understanding of that work through their personal testimonies, this is largely the reason why VDs in general have not formed part of the wider discussion.

139 It seems that this was not entirely universal. In her oral history, Army Sister Mary Haddie Swan stated that penicillin was so precious that they used it only on their own troops in Normandy and not the German troops. Mary Haddie Swan, oral history by Lyn E. Smith, 26 October 1998, IWM Sound Archive 18571.

140 Anonymous, 'Penicillin for P.O.W.', British Medical Journal (7 October 1944): 484.

141 Anonymous, 'News from the nursing world: Professor Florey on penicillin', Nursing Mirror and Midwives' Journal (18 December 1943): 161.

142 Anonymous, 'Penicillin in the field', The Lancet (11 December 1943): 737. In her oral history interview, Ursula Dowling, a Red Cross nurse, discusses meeting Florey in the desert and his experiment on a patient with a gangrenous thigh. She described the effects as 'magic'. Ursula Dowling, oral history interview in 1986 by Rosemary Hart on behalf of the BBC. IWM oral history collection 9910 .

143 H.E. Dale, 'Modern drugs: 3 - Penicillin', Nursing Times (27 November 1943): 883.

144 I.W.J. McAdam, J.P. Duguid and S.W. Challinor, 'Systemic administration of penicillin', The Lancet (9 September 1944): 336.

145 Anonymous, 'Penicillin in the treatment of war wounds', Nursing Times (8 January 1944): 19.

146 M.K.I. Harpin, 'Oral penicillin therapy in the nursing treatment of lobar pneumonia in the MEF'. This article was to be forwarded to the Nursing Mirror and Midwives' Journal, after approval of the General Headquarters. 25 February 1945, MMM QARANC uncatalogued archive.

147 Morris, 'The diary of a wartime nurse' (28 June1944), 116; Morris, A Very Private Diary, 99. 
148 Morris, 'The diary of a wartime nurse' (8 October 1944), 148; Morris, A Very Private Diary, 130.

149 Bolton, The Maturing Sun, 131.

150 Gertrude Annie Cooper (née Ramsden), oral history interview by Margaret Skellern, 10 May 1994. Royal College of Nursing Oral History Archive, Edinburgh.

151 Dyer, 'When life was grey and scarlet', 62-3.

152 Salter, 'Long ago and far away', 147.

153 Luker, 'Preface', 14.

154 Anonymous, 'Penicillin in the field' 737.

155 Both the nursing and medical press published articles throughout 1944 and 1945 detailing the uses, dosages and administrative issues in penicillin. In both sets of professional journals the information given is strikingly similar, suggesting the expectation that both professions needed to learn about the drug and learn the same details. See, for example, Anonymous, 'Editorial: Penicillin treatment reviewed', Nursing Times (22 April 1944): 275; McAdam et al., 'Systemic administration of penicillin', 336-8; Anonymous, 'Penicillin: Indications for its use and methods of administration', Nursing Mirror (14 April 1945):16; Anonymous, 'Penicillin: Indications for its use and methods of administration', The British Journal of Nursing (April 1945): 39.

156 Sister Joan Peake, oral history by her son, Andrew Peake, 17 March 1993, 16. Princess Mary's Royal Air Force Nursing Service, Imperial War Museum, London $94 / 27 / 1$. It is not absolutely clear at what point this was occurring. By 1944 there were reasonable quantities of penicillin being produced and it was therefore used instead of the sulpha drugs for many illnesses and injuries. If this was aa late as 1944, it is not clear why chemists were still producing crude penicillin. Peake's oral history is not particularly clear throughout in terms of timelines, so she could have been referring to earlier experiences in the desert. Kevin Brown identifies that the early researchers in Oxford did not have properly designed culture dishes either and that the team obtained biscuit tins, as well as petrol tins and bedpans, in order to grow the mould. Brown, Fighting Fit, loc. 3546.

157 Anonymous, 'Penicillin in the field', 738.

158 Toman, An Officer and a Lady, 131, 133.

159 Toman, An Officer and a Lady, 119.

160 Sandelowski, 'Venous envy'; Sandelowski, Devices and Desires; Toman, 'Blood work'; Cynthia Toman, "Body work": Nurses and the delegation of medical technology at the Ottawa Civic Hospital, 1947-1972', Canadian Journal of the History of Science, Technology and Medicine 29, 2 (2006): 155-75. 